\title{
Characteristics of Head Teachers in Management of School Facilities in Kenya
}

\author{
John M. Mbunde, PhD \\ Senior Lecturer, Deputy Head of Department, School of Education \\ The Presbyterian University of East Africa, Nairobi, Kenya \\ Jackson M. Njage-Rwito, Ed.D, FKIM, MPTAK
}

Senior Lecturer, Head of Department, School of Education

The Presbyterian University of East Africa, Nairobi, Kenya

Doi:10.19044/esj.2018.v14n25p227 URL:http://dx.doi.org/10.19044/esj.2018.v14n25p227

\begin{abstract}
This paper discusses the characteristics of head teachers in management of school facilities in Kenya. The objective was: to determine the characteristics of head teachers in management of school facilities. The research employed descriptive survey design. The research instrument used was a questionnaire. Descriptive statistics technique was used to analyze the data. Then the data was presented in tables. Conclusions: Age is an important factor in school administration as it influences the authority and experiences of the head teacher; higher levels of education correlate with levels of productivity; qualification and experience enhance the head teachers' expert power, credibility, confidence and decisiveness in managerial practice; head teachers' administration and experience play a pivotal role in determining their attitudes and approaches as well as their problem solving techniques in their schools and participation in in-service training makes head teachers more effective and efficient in management. Recommendations: The Kenya Education Management Institute should organize in-service training programmes targeting head teachers' management; the Ministry of Education, Science and Technology should provide adequate funding to enable the head teachers to participate in the in-service training programmes; also the ministry should reinforce the existing policies laws and enactments to enhance gender equity and the head teachers should be encouraged to continue upgrading their education level and professional qualification to enhance their knowledge, skills, attitudes and competencies in management and head teachers need to have Masters level expertise if they are to lead their schools and help their teachers become fully proficient.
\end{abstract}

Keywords: Characteristics, Facilities, Management 


\section{Introduction}

\section{Background to the study}

Among the options for the future success of education in Europe and Central Asia is effective management of facilities. This can be achieved by sharing common facilities across schools such as playgrounds, swimming pools, libraries and laboratories. Also, there should be use of incentives to reduce negligence of facilities to encourage and reward good school management of facilities (Heyneman, 1994). In the study on management of facilities in the United Kingdom, when games facilities are used they enable the less able children to stay on task and remain motivated for a longer period (Denyer, 1998). In an empirical study in Nigeria, the essential facilities such as equipment like radio, television, computer, chemicals, specimens, radio tape, stove, Bunsen burners, models and charts were not available in schools (Nwoji, 1999). In Kenya a maximum of six textbooks are approved from which a school chooses one textbook per subject (Republic of Kenya, 2006).

The decline in performance in schools is related to poor learning environment created by inadequacy of the schools facilities (Fabayo \& Farombi, 1998). In Latin America, Africa and poor countries, the majority of the teachers not only lack adequate hardware and software, but also reliable internet access (World Bank, 2006). The availability and adequacy of school facilities promote effective teaching and learning process (Mapaderun, 2002; Oni, 1995). Some schools have adequate laboratories, workshops, libraries, and other facilities for effective teaching and learning, others have none, and where they exist they are poorly equipped. While some classes are held under trees and pupils are exposed to harsh weather conditions others are held in air conditioned classrooms. It is therefore, imperative that different levels of Government have to address the issue of development and implantation of minimum standards of school management of facilities (Asiabaka, 2008).

Former Assistant Minister of Education (Kenya), Dr. Kilemi Mweri, addressing a regional workshop for African teachers held on 24-28 September, 2007, Nairobi, on behalf of the Minister for Education, Professor George Saitoti declared that delivery of quality education was hampered by poorly trained teachers, lack of school facilities and lack of structured teacher development programmes which are also key in pupils' performance in KCPE (Ministry of Education, 2007). Some schools are over fifty years old and therefore, require modern facilities for teaching and learning process. Renovation of old and dilapidated buildings need to be carried out to ensure that facilities for teamers, planning areas, office space, clerical space, workrooms, professional development libraries, dining area, storage, space, pupils' conference areas, guidance services area for instruction for large group instruction, space for instructional media, library resource centre, science 
facilities, art and music studios, individual study area and physical education facilities are readily available (Asiabaka, 2008).

The Government has given serious consideration to changes to the 84-4 education structure, the introduction of technical and academic curriculum pathways, and the centrality of Information Communication Technology to teaching and learning process. Sessional Paper No. 1 of 2005 on Policy Framework for Education, Training and Research spells out the education policy towards the realization of the national economic blueprint (Republic of Kenya, 2012). Every child has a right to education. The Children's Act which came into force on $1^{\text {st }}$ March 2002 vests this responsibility on the Kenya Government and parents (Ministry of Education, 2010).

Education has been found to play a major role in social, political, economic and cultural aspects of a country (Mbeche \& Nderitu, 2005). Education provides critical mass of skilled people needed to enhance the environment which is in line with the Millennium Development Goal No.1 (Ministry of Education, 2007). It has been noted that incidences of poverty fall and levels of private returns increase with increase in education level from primary to secondary (Republic of Kenya, 2005; UNESCO, 2005).

There has been criticism on the way the school facilities are managed in Kenya by head teachers (Musera, Achoki \& Mugasia, 2012). The head teachers have to be equipped with relevant knowledge, skills and competences to perform management duties which include planning, organising, staffing, directing, coordinating, reporting and budgeting (Ngaroga, 2001). However, the implementation of Free Primary Education in Kenya found head teachers had not been adequately prepared for the change and therefore, found it challenging (Republic of Kenya, 2005).

Despite the heavy investment in education, management capacity remains ineffectively developed (Maranga, 1992). Just as societal and school demographics have changed in recent decades, so has the type of leadership needed to successfully head the rapidly changing school of this century (Meleod, 2008). It is undisputed that the head teacher is the most significant factor in enhancing school performance (Dinham, 2004; Kearney, 2005; Janerrete \& Sherrete, 2007; Gentilucci \& Muto, 2007). Successful and dynamic schools can quickly slide backwards with the departure of a successful head teacher (Hargreaves \& Fink, 2004). Head teachers are critical in ensuring that school management efforts are successful (Rutledge, 2009).

Serious challenges have faced the implementation of the Free Primary Education policy in Kenya (UNICEF \& World Bank, 2009). They include delays in funds disbursement, congested classes (teacher to pupil ratio of 1:70 from 1:40) in some schools, shortage of supplementary reading books and school facilities (textbook to pupil ratio of 1:5) has affected pupils' accessibility to books while at home (Okwacha \& George, 1997). Parents cite 
performance of a school as their main reason for transferring their children from one school to another (UNICEF \& World Bank, 2009). Although priorities vary significantly from school to school, the majority of the schools have overcrowded classrooms and inadequate water and sanitary facilities and a huge deficit of furniture. The requirement for additional investment in primary school facilities is particularly acute in urban slums and the poorest areas in Kenya. In some of these ASAL areas primary school enrolment remains low and inadequate school facilities is one of the barriers to children influencing the education system (Ministry of Education, 2013).

The significance of Kenya Certificate of Primary Education (KCPE) is to: serve as a feedback to the education planners, Kenya National Examinations Council, teachers, pupils, parents and other stakeholders; planners can use it to modify, introduce or drop a topic or subject; screening/selection, for further studies, training; research work and certification (Ayot \& Patel, 2000; Ministry of Education, 2009).

Acquisition of literacy and numeracy skills are conditions for a better life. Better life is attributed to awareness to good life and access to basic needs, change for income generating and good health. Literacy and numeracy are important for human development index (UNDP, 2006). These are key skills that primary education is supposed to achieve as indicated in the primary education objectives. The national goals of education in Kenya and the primary education level objectives reflect the importance of primary education. In particular, the objectives of primary education are carried out in producing Kenyans who have knowledge and skills that enables them to fit in the society. This is reflected in many key Government documents. Key among them is the National Development Plan of 2002-2008 in which the Government has identified education as key to the attainment of the Millennium Development Goals and Education For All (Republic of Kenya, 2002).. They acknowledge that a weak educational foundation will seriously impair a nation's development progress. Effective primary education is a rock-bottom necessity for development. The effects of primary education in development are largely a result of the cognitive skills: literacy, numeracy and problem solving.

Poor primary schools compromise the entire system for human capital development. They provide graduates who are poorly prepared for secondary and tertiary education and ill-equipped for life-long learning. The consequence is an insufficient number of truly educated managers, workers and parents who can effectively contribute to development. The most effective sign of ineffective primary education systems are inadequate enrolments, low primary completion and low pupil achievement (World Bank, 1995).

The mass media analyze, and publish KCPE results and have to rank and highlight the schools which have performed well (Abagi \& Odipo, 1997). The quality of education in Kenya is examination oriented. The quality of 
education is seen in terms of pupils passing national examinations (Eshiwani, 1993).

The management of school facilities such as equipment, furniture, playgrounds, stationery and buildings enhances performance in the teaching and learning process. Teachers and pupils need facilities to search, read, write, confer, interact, view, listen, think, experiment and record. Teachers need office space, staffrooms for team planning, rooms for diagnosis for pupils' needs, and preparing instructional presentation (Asiabaka, 2008). The availability and adequacy of the school facilities promote effective teaching and learning process in schools while their inadequacy affects the academic performance negatively (Mapaderun, 2002; Oni, 1995). School facilities can only be utilized when they are available, and that there has to be investment in this wisely in educational institutions (Akano, 2005; Eze, 2002). Management of facilities by head teachers ensures that buildings, equipment, furniture, stationery and playgrounds support the operations of a school. The physical needs of the pupils are met through provision of physical facilities. The emotional needs are met by creating pleasant surroundings, a child-friendly stimulating atmosphere and an inspiring environment (Fenker, 2004).

The management of school facilities involves provision of adequate funds to procure new facilities; repair, maintenance and improvement of facilities to enhance academic performance. This can be achieved by formulating policies and communicating them to the Board of Management and staff. The head teachers are to allocate duties to staff in accordance with expertise and abilities, influence and stimulate staff and provision of an enabling school climate for academic performance. The head teachers' skills direct school structure and its staff towards a deliberate integration of both the school and personal goals (Okumbe, 1998)

Characteristics refer to the features of somebody. The characteristics of the head teachers discussed in this paper are age, gender, education level, professional qualification, work experience and participation in in-service training. These characteristics enhance the head teachers' management of School Facilities.

\section{Statement of the problem}

There are inequitable gender disparities. Age is an important factor in school administration as it influences the authority and experiences of the head teacher (Mbiti, 2007). Higher levels of education correlate with levels of productivity. Qualification and experience enhance the head teachers expert power, credibility, confidence and decisiveness in managerial practice (Okumbe, 1999). Head teachers' administration and experience play a pivotal role in determining their attitudes and approaches as well as their problem solving techniques in their schools (Ouru, 2008). Therefore, there was need to 
carry out the research to determine the characteristics of head teachers in management of school facilities.

\section{Research objective}

To determine the characteristics of head teachers in management of school facilities in Kenya.

\section{Research methodology}

The researchers opted to use a sample size of 20 percent of the 204 public primary schools since the study involved mixed quantitative and qualitative approaches. The research instrument used was a questionnaire. The validity of the instrument was determined by the staff from the Department of Educational Administration and Planning of the University of Nairobi. Pilot tested instrument was subjected to split-half technique. This involved a single administration of the instruments, then splitting items into two halves, odd and even numbered method. A reliability coefficients value of 0.73 was found.

\section{Research findings and discussions}

\section{Research Question 1: What is your gender?}

The head teachers were asked to state their gender and the results are shown in Table 1.

Table 1: Distribution of the head teachers by gender

\begin{tabular}{lcc}
\hline Gender & Frequency & Percentage (\%) \\
\hline Female & 26 & 63.0 \\
Male & 15 & 37.0 \\
\hline Total & $\mathbf{4 1}$ & $\mathbf{1 0 0 . 0}$ \\
\hline
\end{tabular}

It is observed from Table 1 results that majority, 63.0 percent of the head teachers who participated in the survey were females representing more than a half of the head teachers who participated while male head teachers were 37.0 percent. Therefore, the great majority of head teachers in Kenya are female. Gender refers to whether an individual is female or male. Daft (2008), noted that female managers are rated higher by subordinates on interpersonal skills as well ads on factors such as behaviour, communication and the ability to motivate others. Male leaders tend to be competitive and individualistic. There are inequitable gender disparities. More pronounced disparities exist in arid and urban conglomerations (Republic of Kenya, 2012). Although the Kenyan Constitution and even the education legislative enactment give evidence of the Government's commitment to gender balance at all levels of education, there are still great disparities between men and women's 
participation in education (Davidson, 1993). The high sounding policies, laws and enactments have not translated into gender equity in education at all levels (Abagi, Olweya \& Otieno, 2000).

\section{Research Question 2: What is your age bracket?}

The head teachers were asked to indicate their age bracket and the results are shown in Table 2.

Table 2: Distribution of the head teachers by age

\begin{tabular}{lcc}
\hline Age bracket (Years) & Frequency & Percentage (\%) \\
\hline $41-45$ & 3 & 7.0 \\
$46-50$ & 15 & 37.0 \\
51 and above & 23 & 56.0 \\
\hline
\end{tabular}

Total

41

100.0

The findings in Table 2 indicate that majority of the head teachers, 56.0 percent were in the age bracket 51 and above and only 7.0 percent were in the age bracket 41-45. Thus, the great majority of head teachers in Kenya are at least 51 years old. The age factor is an important factor in management as it influences the authority and experiences of the head teacher (Mbiti, 2007). The older head teachers seem to be motivated in their work up to the time of retirement (Cole, 2005). An individual's age determines the precision and the vigour with which a person performs tasks, hence influences the head teachers' dealing with the school management of facilities. Older teachers are less ambitious and have no interest in recognition. Also; they are less motivates to take action on pupils (Ouru, 2008). Age of a head teacher has an effect on their attitudes and could influence their preferred choice of action on school issues (Mukiri, 2003; Getrude, 2006; Ouru, 2008).

\section{Research Question 3: What is your educational level?}

The head teachers were asked to state their education level and the results are shown in Table 3.

Table 3: Distribution of the head teachers by education level

\begin{tabular}{lcc}
\hline Education level & Frequency & Percentage (\%) \\
\hline Teachers Training College & 8 & 20.0 \\
University & 33 & 80.0 \\
\hline Total & $\mathbf{4 1}$ & $\mathbf{1 0 0 . 0}$
\end{tabular}

The results in Table 3 show that majority, 80.0 percent of the head teachers attained university education level while 20.0 percent had Teachers 
Training College education level. Hence, the great majority of head teachers in Kenya are university trained. Higher levels of education correlate with levels of productivity. The empirical studies point to the greater capacity of educated employees learns on the job and continues to improve on their productivity (Oxaal, 1997). Education opens the mind of an individual to strategic thinking, better problem solving approaches and planning with a view of reducing casers of indiscipline among pupils (Cheloti, 2009).

\section{Research Question 4: What is your professional qualification?}

The head teachers were asked to indicate their professional qualification and the results are shown in Table 4.

Table 4: Distribution of the head teacher by professional qualification

\begin{tabular}{lcc}
\hline Professional qualification & Frequency & Percentage (\%) \\
\hline P2 & 3 & 7.3 \\
P1 & 5 & 12.2 \\
Diploma & 10 & 24.4 \\
B.Ed/BA & 16 & 39.0 \\
Masters & 7 & 17.1 \\
Total & $\mathbf{4 1}$ & $\mathbf{1 0 0}$
\end{tabular}

The findings in Table 4 indicate that the highest proportion of the head teachers, 39.0 percent were holders of B. Ed/B.A and lowest, 7.3 percent holders of P2. Education enhances proficiency, operational and conceptualization skills of an individual (Sisungo, Buhere \& Sany, 2011). The professional qualification of head teachers is a major factor for effective curriculum implementation. This is also in extension significant in management of facilities by the head teachers (Ministry of Education, 2007). However, the university educational training of head teachers is severely lacking. Over $40 \%$ of head teachers have less than a bachelor's degree in education. Only $17 \%$ have a Masters degree which is considered the highest level of expertise. Compared to Western nations, the master's degree is required for all educational administrators and most have significant experience in both financial and school planning during their Masters programme. Qualification and experience enhance the head teachers expert power, credibility, confidence and decisiveness in managerial practice (Okumbe, 1999).Teacher education is largely a matter of developing teachers capacities for situational understanding as a basis for wise judgement and intelligent decisions in completely ambiguous and dynamic educational situations (Lam \& Fung, 2001). 
Head teachers need to have Masters level expertise if they are to lead their schools and help their teachers become fully proficient. School leaders need to know the latest educational practices in order to make students more competitive. While this will obviously involve increase educational costs, the benefits to teachers who help our students learn as well as the students themselves are well worth the investment.

\section{Research Question 5: What is your work experience as a head teacher?}

The head teachers were asked to indicate their work experience as head teachers and the results are shown in Table 5.

Table 5: Distribution of the head teachers by work experience as head teacher

\begin{tabular}{lrc}
\hline Work experience (Years) & Frequency & \multicolumn{2}{c}{ Percentage (\%) } \\
\hline 1-5 years & 7 & 17.0 \\
6-10 years & 15 & 37.0 \\
11-15 years & 9 & 22.0 \\
16 and above years & 10 & 24.0 \\
\hline Total & & $\mathbf{1 0 0 . 0}$ \\
\hline
\end{tabular}

The data shown in Table 5 indicates that the highest proportion, 37.0 percent of the head teachers who participated in the survey had worked for a period between 6-10 years, and lowest 17.0 percent $1-5$ years. Over $80 \%$ had at least five years of teaching experience. Available literature indicates a strong relationship between student examination outcome and the teacher's years of teaching experience (National Centre for Education Statistics (NCES), 2000; Rowan, Correnti \& Miller, 2002). Teachers with few years of experience, usually three years and below are less effective compared to those of more years of experience. However, beyond five years of teaching experience the influence deceases. This may suggest that experience of ten years may not have significant difference in performance when compared with the counterpart with five years teaching experience (Darling-Hammond, 2000). Therefore the head teachers' experience in years may determine their effectiveness in management of school facilities. As opposed to the number of years the head teacher has been teaching, the years the head teacher has been in leadership position is important. The experience could improve decision making.

Schools that have long serving and experienced head teachers have less discipline problems (Mutisya, 2000; Eshiwani, 1993). Such schools may not vandalise school facilities. Head teachers who have served for a long period of time in the same school administratively do better than those who spend a few years. A study reported that long-serving head teachers have time to interact and understand the needs of their teachers and are able to initiate changes for 
teacher growth for academic performance (Vanderhaar, Marioz \& Rodosiey, 2006).

Work experience could improve decision-making, effectiveness and efficiency ((Okoth, 2008).

Head teachers' administration and experience play a pivotal role in determining their attitudes and approaches as well as their problem solving techniques in their schools (Ouru, 2008).Long leadership experience is linked to settled families and minds hence ability to concentrate on school matters (Mwende, 1995). The school matters cold entail among others head teachers' management of facilities. Head teache5rs with many years of experience in handling pupils have better understanding of their pupils and roles as head teachers (Ouru, 2008).

\section{Research Question 6: How many times do you participate in in-service training per year that involved management of facilities?}

The head teachers were asked to indicate their participation in inservice training of head teachers that involved management of facilities and the results are shown in Table 6.

Table 6: Distribution of the head teachers' participation in in-service training

\begin{tabular}{lcr}
\hline Number of in-service training per year & Frequency & Percentage $(\%)$ \\
\hline No in-service & 4 & 9.8 \\
Once & 9 & 22.0 \\
Twice & 15 & 36.5 \\
Thrice & 13 & 31.7 \\
\hline Total & $\mathbf{4 1}$ & $\mathbf{1 0 0 . 0}$ \\
\hline
\end{tabular}

The findings in Table 6 indicate that the highest proportion, 37.0 percent of the head teachers who participated in the survey had participation in in-service training twice and lowest 10.0 percent had no in-service training. Participation in in-service training makes head teachers be rated higher in relationship oriented leadership as they are perceived as being friendlier, listened more to teachers and avoided being impatient which are characteristics of warm working environment (Okoth, 2000).

The development of head teachers' skills through in-service training undertakes the desired duties and raising their confidence about their capacities is an important step in involving the social curriculum (Commonwealth Secretariat, 2005). There is need to have a forum where ideas can be shared among the members of the school or schools (Checkly, 2000). Studies indicate that female teachers' perception of utilization of resources is significantly lower than their male counterparts. Therefore, there is need to train and retrain 
teachers on improvisation and utilization of materials-resources for effective teaching (Olagunju, 2003; Awoniyi, 1999).

In-service training is also lacking particularly because head teachers are deficient in educational administration practices. Over $30 \%$ of head teachers have only one in service is less during the school year. In comparison, in most Western nations school leaders have training monthly or at least 10 times per year. In looking at our research, the increased training of our head teachers is paramount. If Kenya is going to have student graduates that are competitive in a global economy, then our head teachers must have training that is comparable to that of western nations.

\section{Conclusion}

- Age is an important factor in school administration as it influences the authority and experiences of the head teacher.

- Higher levels of education correlate with levels of productivity.

- Qualification and experience enhance the head teachers' expert power, credibility, confidence and decisiveness in managerial practice.

- Head teachers' administration and experience play a pivotal role in determining their attitudes and approaches as well as their problem solving techniques in their schools.

- Participation in in-service training makes head teachers more effective and efficient in management.

\section{Recommendations}

- Based on the findings of the research, it was recommended that Kenya Education Management Institute (KEMI) should organize in-service training programmes targeting head teachers' management.

- The Ministry of Education, Science and Technology should provide adequate funding to enable the head teachers to participate in the inservice training programmes.

- The Ministry of Education, Science and Technology should reinforce the existing policies laws and enactments to enhance gender equity.

- The head teachers should be encouraged to continue upgrading their education level and professional qualification to enhance their knowledge, skills, attitudes and competencies in management.

- Head teachers need to have Masters level expertise if they are to lead their schools and help their teachers become fully proficient. School leaders need to know the latest educational practices in order to make students more competitive. While this will obviously involve increase educational costs, the benefits to teachers who help our students learn as well as the students themselves are well worth the investment. 


\section{References:}

1. Abagi, O. Olweya, I. \& Otieno, W. (2000). Counting the social impact of schooling: what Kenyans say about their school system and gender relations. Nairobi: Institute of Policy analysis and research.

2. Akano, B. U. (2005). The use of the local materials in the teaching and learning of science in the primary school. A paper presented in the $1^{\text {st }}$ science Workshop, Science teachers association of Nigeria on May, 2005 at FCE Kontangora.

3. Asiabaka, P. I. (2008). The need for effective facility management in schools in Nigeria. New York Science Journal. 2008:1(2) 10-21. Retrieved on $20^{\text {th }} \mathrm{July}, 2013$ from http//www.sciencepub.org.

4. Ayot, H. O. \& Briggs, H. (1992). Economics of education. Nairobi: Education Research and Publications.

5. Awoniyi, M. A. (1999). Selection and designing of instructional materials aids. Ibadan University Press, 50-51.

6. Bakare-Yussuf, B. (2003). Beyond determination: The phenomology of African a male existence, feminist Africa 2003, issue 2.

7. Best, J. W. \& Khan, J. V. (2004). Research in education ( $7^{\text {th }}$ ed.). New Delhi: Prentice Hall.

8. Checkly, K. (2000). The contemporary principal, new skills for a new age. Education update, May, 43 (3) 1, 4-6, 8.

9. Cheloti, S. K. (2009). Principals' management styles and students' unrest in public secondary schools in Nairobi province. Unpublished, M. Ed, Project. Nairobi: University of Nairobi.

10. Cole, G. A. (2005). Management: theory and practice (6 ${ }^{\text {th }}$ ed.), London: Thompson Learning.

11. Commonwealth Secretariat. (2005). Promising practices and implications for schooling up girls. Education report of the UN girls education initiative South Asia workshop held in Chandigarh India, 2022 September, 2004.

12. Daft, R. L. (2008). The leadership experience (4 ${ }^{\text {th }}$ ed.).US:Thomson South Western.

13. Darling-Hammond, L. (2000).Teacher quality and student achievement: A review of state policy evidence. Education Policy Analysis Archives 8 (1). htpp://epa.asu.edu

14. Davidson, J. (1993). School attainment and gender. Attitudes of Kenyan and Malawian parents towards educating girls. International Journal of education, 13 (4), 331-338.

15. Denyer, G. (1998). Science games in the national curriculum. Science Education Newsletter, 140, 5-6. 
16. Dinham, S. (2004). "Principals' leadership for outstanding outcomes". Journal of Educational Administration, 43 (4), 338-356.

17. Eshiwani, G. S. (1993). Education in Kenya since independence. Nairobi: East African Publishers, Kenya.

18. Eze, S. U. (2002). Effect of target task approach on pupils' achievement and interest in senior secondary school physical chemistry. Unpublished PhD, Thesis. Nsukka: University of Nigeria.

19. Fabayo, O. R. (1998). Evaluation of some aspects of schools quality in secondary schools in Kwara state. Unpublished PhD, Thesis. Ibadan: University of Ibadan.

20. Farombi, I. (1998). Resources concentration utilization and management as correlates of pupils' learning outcomes study of quality in oyo state. Unpublished PhD, Thesis. Ibadan: University of Ibadan.

21. Fenker, M. (2004). Organizational change, representatives and facilities. In facilities management: innovation and performance. Alexander, K. (ed.). U.K: Taylor Francis.

22. Getrude, S. A. (2006). Guidance and counselling as a professional. Nairobi: Jomo Kenyatta Foundation.

23. Goh, S, C. \& Fraser, B. J. (2000). Teacher interpersonal behaviour and elementary students' outcomes. Journal of Research in Childhood Education, 14, 216-231.

24. Hargreaves, A. \& Fink, D. (2004). "The seven principals of sustainable leadership". Educational Leadership, 61 (7), 8-13.

25. Heyneman, P. (1994). Education in Europe and Central Asia region :poleis of adjustment and excellence. London: World Bank.

26. Janereette, D. \&Shereetz, K. (2007). School leadership and student achievement. Educational Policy Brief. Retrieved on February $5^{\text {th }}$, 2018 from http://www.educ.de.edu.

27. Lam, J. \& Fungu, Y. M. (2001). Strengthening teacher training programme: Revamping the model of teaching practice. A paper presented at the $2^{\text {nd }}$ Hong Kong Conference on quality in teaching and learning in higher education on $3^{\text {rd }}-5^{\text {th }}$ May 2001.

28. Mbiti, D. M. (2007). Foundations of administration. Nairobi: Oxford University Press.

29. Mapaderun, O. (2002). Teaching method of business, social science and technical education. Ibadan: Holyem Communications.

30. Maranga, J. S. (1992). Suggestions for improving teaching, learning, administration and supervision., future perspectives on teacher preparation for Basic Education For All for the $21^{\text {st }}$ Century. Basic Education Forum. 
31. Mbeche, F. \& Nderitu, A. (2005). Educational policy and Planning. The Flemish association for development and technical assistance, 2005, Nairobi.

32. Meleod, I. N. (2008). Exploring the relationship between school leadership and middle school mathematics achievement: an examination of leadership practices of principals. Unpublished $\mathrm{PhD}$, Dissertation. Maryland: University of Maryland, College Park.

33. Ministry of Education. (2013), Basic Education Act, 2013. Nairobi: Ministry of Education.

34. Ministry of Education. (2010), Elimu News issue No. 5. Nairobi: Ministry of Education.

35. Ministry of Education. (2009), Teachers training proficiency course training manual. Nairobi: Ministry of Education.

36. Ministry of Education. (2007). Kenya education sector support programme. "School infrastructure technical handbook". School infrastructure management unit. Version one 2007. Nairobi: Ministry of Education.

37. Mukiri, R. T. (2003). Introduction to guidance and counselling in schools and colleges. Nairobi: Oxford University Press.

38. Musera, G. Achoka, J. \& Mugasia, E. (2012).Perception of secondary school teachers on principals' leadership styles in school management in Kakamega central district, Kenya. Implications for Vision 2030. International Journal of Humanities and social Sciences, Vol.2 No. 6 (Special issue March 2012.

39. Mutisya, S. S. (2000). Parental guidance: Family magazine. Nairobi: Uzima Publications Limited.

40. Mwende, S. M. (1995). Causes and consequences of drug abuse by secondary school students in Tigania North district. Unpublished, Post Graduate Diploma, Thesis. Nairobi: Kenyatta University.

41. National Centre for Educational Statistics. (2000). Monitoring school quality. NCES 2001-030. Washington DC: US Department of Education, Office of Education, Research and improvement.

42. Ngaroga, M. (2001). PTE revision education. Nairobi: East African Publishers.

43.Nwoji, J. R. (1999). Evaluating the use of learning resources for primary science education. Implications for learners: $40^{\text {th }}$ annual conference proceedings of STAN, 245-249.

44. Okoth, U. A. (2008). Instructional leadership role of head teachers in the implementation of secondary school environmental education in Siaya district, Kenya. Unpublished $\mathrm{PhD}$, Dissertation. Nairobi: Catholic University of Eastern Africa. 
45. Okoth, U. A. (2000). A study of the effect of leadership styles in performance in KCSE Examinations in Nairobi province. Unpublished M.Ed, Thesis. Nairobi: University of Nairobi.

46. Okumbe, J. A. (1999). Educational management: theory and practice. Nairobi: Nairobi University Press.

47. Okumbe, J. A. (1998). Educational management: theory and practice. Nairobi: Nairobi University Press.

48. Okwach, A. \& George, O. (1997). Efficiency of primary education in Kenya: situational analysis and implications for educational reform. Nairobi: Institute of Policy Analysis and Research.

49. Olagunju, A. M. (2003). Science education pupils' level of awareness and utilization of information and communication technology: implications for tertiary institutions. Proceedings of the $44^{\text {th }}$ annual conference of science teachers association of Nigeria, 99-104.

50.Oni, J. O. (1995). Education resources: An introduction. Abeokuta: Gbernisodipo Press Limited, 1-21.

51. Ouru, J. N. (2008). Principals' and students' attitudes towards guidance and counselling and maintenance of discipline in secondary schools in Nyamira District, Kenya. Unpublished PhD, Thesis. Nairobi: University of Nairobi.

52. Oxaal, Z. (1997). "Education and poverty: A gender analysis". Report No. 53 BRIDGE. Brighton: Institute of Development Studies, University of Sussex.

53. Republic of Kenya. (2012). A policy framework for education. Task force on the re-alignment of education sector to the constitution of Kenya 2010: towards a globally competitive quality education for sustainable development report of the task force. Nairobi: Government Printers.

54. Republic of Kenya. (2006). Approved list of primary and secondary schools textbooks and other instructional materials. Nairobi: Government Printers.

55. Republic of Kenya. (2005). A policy framework of education, training and research. Sessional Paper No. 5. Nairobi: Government Printers.

56. Republic of Kenya. (2005). A policy framework of education, training and research. Sessional Paper No. 1 o 2005f. Nairobi:. Government Printers.

57. Republic of Kenya. (2005). The economic recovery report. Nairobi: Government Printers.

58. Republic of Kenya. (2002). Report of the sector review and development direction. Nairobi: Government Printers.

59. Rowan, B. Correnti, R. \& Miller, R. S. (2002).What large- scale survey research tells us about teacher effects on student achievement: insights 
from the prospects study elementary schools. Teachers College Record 104 (8) 1525-67.

60. Rutledge, L. (2009). Teacher leadership and school improvement: a case study of teacher participating in the teacher leadership network a regional service education centre. Unpublished PhD, Dissertation.San Marcos: Graduate Council of Texas State University.

61. Sisungo, Z. W., Buhere, P. \& Sany, A. K. (2011). Innovation in secondary schools management practices for efficiency and development. Kenya Journal of Education Planning, Economic and Management, Vol.3, 1-10.

62. Vanderhaar, J. E. Murioz, M. A. \& Rodosky, R. J. (2006). Leadership as accountability for learning The effects of school poverty, teacher experience, previous achievements and principals preparation programme on students achievement. Journal of Personnel in Education, 19, 17-33.

63. UNICEF \& World Bank. (2009). Africa Human Development Series, Development practice in education. Washington DC: World Bank Publications.

64. World Bank. (2006). How do ICT education institutions contribute to the millennium development goals? Retrieved on $6^{\text {th }}$ May, 2013 from www.worldbank. Org|website|external|topics.

65. World Bank. (1995). Policy paper on primary education. Nairobi: World Bank. 